\title{
Effects of "soil-like" particle size on gas transport and water retention properties in aged municipal solid waste from a Sri Lankan open dumpsite
}

\author{
M. Shanujah ${ }^{1}$ \\ T. K. K. Chamindu Deepagoda ${ }^{1}$ \\ M. C. M. Nasvi ${ }^{1}$ \\ V. Shreedharan ${ }^{3}$ \\ G. L. S. Babu ${ }^{4}$ \\ A. K. Karunarathna ${ }^{2}$ \\ Curtis M. Oldenburg ${ }^{6}$ \\ Kathleen M. Smits ${ }^{5}$
}

${ }^{1}$ Dept. of Civil Engineering, Faculty of Engineering, University of Peradeniya, Peradeniya 20400, Sri Lanka

2 Dept. of Agricultural Engineering, Faculty of Agriculture, University of Peradeniya, Peradeniya 20400, Sri Lanka

${ }^{3}$ Government College of Engineering, Kannur, India

${ }^{4}$ Indian Institute of Science, Bangalore, India

${ }^{5}$ Dept. of Civil Engineering, University of Texas, Arlington, TX 76019, USA

${ }^{6}$ Energy Geosciences Division, Lawrence Berkeley National Laboratory, 1 Cyclotron Road, Berkeley, CA 94720, USA

\section{Correspondence}

Chamindu Deepagoda T.K.K., Dept. of Civil Engineering, University of Peradeniya, 20400 Peradeniya, Sri Lanka. Email:Chaminduk@pdn.ac.lk

\section{Funding information} Indian-Sri Lankan Inter Governmental Science and Technology Co-operation Programme; India-Sri Lanka Foundation

\begin{abstract}
Open dumps constitute a major source of greenhouse gases (GHGs), predominantly methane and carbon dioxide, in developing countries. In an aged dump, typical waste composition is dominated by the "soil-like" fraction of which physical, hydraulic and gas transport characteristics markedly affect GHG emissions. This study characterized soil-gas diffusivity $\left(D_{\mathrm{p}} / D_{0}\right)$, soil-water characteristics (SWC), and particle size distribution in "soil-like" fractions of aged solid waste retrieved at 2.5-5 m depth from an old open dumpsite situated at Kurunegala, Sri Lanka. The "soil-like" fraction was proportioned into three groups based on particle size $(0-4.75,4.75-9.5$, and $9.5-25 \mathrm{~mm})$ to investigate the particle size effect on $D_{\mathrm{p}} / D_{0}$ and SWC. The simulated methane concentration profiles in different size groups were also examined using the transport simulator TOUGH2-EOS7CA based on the multiphase flow of multicomponent gas mixture (methane, water vapour and air) under dry and half-saturation conditions across a predefined temperature gradient. The results highlighted distinct two-region characteristics (i.e., inter-aggregate and intra-aggregate pore regions) in all three size fractions which could be adequately parameterized with existing and modified bimodal functions. We proposed a useful practical tool for estimating $D_{\mathrm{p}} / D_{0}$ for known mean particle size and volumetric water content in the absence of direct measurements. The results further revealed that $D_{\mathrm{p}} / D_{0}$ is particle-size dependent; however, $D_{\mathrm{p}} / D_{0}$ remained invariant across all size fractions at the volumetric water content of $\sim 0.22-0.25 \mathrm{~cm}^{3} \mathrm{~cm}^{-3}$. Numerical results further showed a pronounced effect of particle size and soil moisture on gas transport properties.
\end{abstract}

\section{1 | INTRODUCTION}

Abbreviations: GHG, Greenhouse gas; LFG, Landfill Gas; MSW, Municipal Solid Waste; SWC, Soil-water characteristics; PSD, Particle size distribution; ADC, Analog-to-Digital Converter; IPCC, Intergovernmental Panel on Climate Change
Rapid urbanization and economic growth, changing lifestyles of people, land use patterns and technological advancements have led to an increase in the quantity, 
composition, and complexity of urban Municipal Solid Waste (MSW). MSW generally comprises degradable (food waste, paper, textiles, straw and yard waste), partially degradable (sludge, wood and disposable napkins) and non-degradable (metals, leather, plastics, rubbers, metals, glass, ash from fuel-burning like coal and electronic waste) materials. Management of MSW has become a critical environmental concern because most solid waste is disposed in open dumps. Such disposal is particularly common in many developing countries due to the economic and technological barriers in waste disposal and nonavailability of skilled laborers.

In Sri Lanka, between 1999 and 2009, the amount of daily-generated solid waste rose from an estimated 6,500 tons to 7,500 tons (Vidanaarachchi, Yuen, \& Pilapitiya, 2006). The predominant MSW ( $\sim 0.56 \mathrm{w} / \mathrm{w})$ is biodegradable with the potential to produce $29 \mathrm{~kg}$ of methane from each 1 ton of biodegradable waste (Menikpura, Gheewala, $\&$ Bonnet, 2012). MSW generation per capita in Sri Lanka was $0.89 \mathrm{~kg}$ per day in 1999 , and it has been predicted to reach $1.0 \mathrm{~kg}$ per day by 2025 (World Bank, 1999). Recent statistics reveal that as much as 85 percent of MSW generated in Sri Lanka is disposed at open dumpsites while the remaining wastes is disposed at fully or partly engineered landfills (Danthurebandara, Van Passel, \& Van Acke, 2015). There are nearly 236 large-scale waste open dumps islandwide while only a handful of fully or partly engineered landfills are available across the country. Both open dumps and engineered landfills in Sri Lanka lack the means for controlling gas emission (Sri Lanka Ministry of Environment, 2011) and the MSW is being dumped without any pre-treatment. In fact, 17 out of 20 Sri Lankan controlled dumpsites, which were recently inspected for gas monitoring showed that the methane concentration is well above the life-threatening limit (Herath, 2015). While the statistics of Sri Lankan landfill emission footprint remains piecemeal, the global estimates show that the landfills contribute $40 \mathrm{Tg} \mathrm{yr}^{-1}$ methane and produce $35 \%$ of the climate forcing by carbon dioxide during the past 150 years (Lelieveld, Crutzen, \& Dentener, 1998).

Accumulation of MSW on a regular basis for a long period of time may potentially provide favorable conditions for the aerobic and anaerobic decomposition of organic matter, yielding in-situ landfill gases comprising mainly of methane and carbon dioxide. The migration and emission of landfill gas may cause negative impacts in the surroundings, for example, fire and explosion hazards, health risks, damage to vegetation, odour nuisances, groundwater contamination, and global climate effects (Kjeldsen, 1996). A four-phase characterization of refuse decomposition (Barlaz, Schaefer, \& Ham, 1989) consists of an aerobic phase, an anaerobic acid phase, an accelerated methane production phase and a decelerated methane

\section{Core Ideas}

- Typical aged waste composition is dominated by the "soil-like" fraction.

- Gas diffusivity and water retention properties showed strong bimodal behavior in the soillike" fraction.

- Simulated subsurface methane concentration profiles varied markedly across different size fractions.

production phase. The last phase of decomposition, which occurs after few years of the waste has been disposed, involves a constant production rate of gas comprising $60 \%$ and $40 \%$ of methane and carbon dioxide, respectively (Crawford \& Smith, 1985; Young, Parker, \& Brookes, 1982); however, gas will continue to be emitted for 50 or more years after the waste is placed in the landfill (Crawford \& Smith, 1985).

Previous investigations made by Cossu et al. (1995), Kaartinen, Sormunen, and Rintala (2013), Quaghebeur et al. (2013), Krook, Svensson, and Eklund (2012), and Wolfsberge et al. (2014) reported that the aged waste from an old open dump normally consists of $0.20-0.30 \mathrm{w} / \mathrm{w}$ combustible materials, $0.50-0.60 \mathrm{w} / \mathrm{w}$ fine-grained solid particles, $0.10 \mathrm{w} / \mathrm{w}$ inert materials and a small percentage of metals. The fine-grained portion is referred to as "soillike" fractions, due to their appearance, organic matter and mineral contents, and relatively homogeneous composition (Quaghebeur et al., 2013), making up a considerable portion of the total waste. This "soil-like" fraction of waste is particularly characterized by high porosity, high infiltration rate, high water-holding capacity, and low shear strength (Cheng-liang, Jing-jing, Ting-ning, \& Li-ming, 2016), which are typical to aggregated agricultural soils. Owing to their similarities with natural soil, many previous studies indicated this fine material as "soil-like" fraction (e.g., Abreu \& Vilar, 2017; Cheng-liang et al., 2016; Mohit, Manoj, Ramana, \& Sreekrishnan, 2018; Quaghebeur et al., 2013). The high soil-like content in the aged MSW is likely the result of daily covering soil, street sweepings, drain silt, and construction and demolition waste along with the humification of organic matter in the fresh MSW (Parrodi, Hollen, \& Pomberger, 2017). Notably, Humus is the stable state reached by organic matter after being degraded down to the point where organic matter resists further degradation and constitutes one of the main components of soil, together with liquid, gases, minerals and living microorganisms (Stevenson, 1994). However, the chemical and biochemical characteristics of the soil-like matter in aged 
MSW may differ from those of natural soil due to the presence of heavy metals and other trace elements (Mohit et al., 2018).

While waste mining from old disposal sites has been a common practice in the world, most of the previous studies focused on characterizing the waste in differently aged waste layers (Burlakovs et al., 2016; Kaartinen et al., 2013). Recovering and recycling valuable materials (e.g., construction materials, combustibles materials and metals) using different mechanical treatment processes (Krook et al., 2012; Kurian, Esakku, \& Nagendran, 2007) has been the main focus of these studies. Only a limited number of studies; however, extended to investigate LFG emission resulting in mining operations such as excavation, processing, transportation (Hölzle, 2018). Although several experimental studies (e.g., Bloltze \& de Freitas, 1995; Christophersen \& Kjeldsen, 2001; Whalen \& Reeburgh, 1988) as well as numerical investigations (e.g., Fadel, Findikakis, \& Leckie, 1996; Visscher \& Van Cleemput, 2003) have been devoted to measure and model the surface emissions from an old open dump, subsurface landfill gas migration in an old open dump, particularly through the "soil-like" fraction, has not been adequately studied.

Due to the lack of bottom liner and inadequate cover layer in typical open dumps, landfill gases can potentially migrate from the deep depth of the old dumps to the atmosphere. In the absence of induced forcing, which is typically the case in the deep unsaturated landfill materials, gas transport through "soil-like" fraction becomes essentially diffusion-controlled, and is commonly described by the dimensionless gas diffusivity $\left(D_{\mathrm{p}} / D_{0}\right.$, where $D_{\mathrm{p}}$ $\left(\mathrm{cm}^{2} \mathrm{~s}^{-1}\right)$ and $D_{\mathrm{o}}\left(\mathrm{cm}^{2} \mathrm{~s}^{-1}\right)$ are gas diffusion coefficients in soil and free air, respectively). Essentially, $D_{\mathrm{p}} / D_{0}$ is strongly related to the air-filled porosity and the tortuosity of the functional gaseous phase in the porous system. Since the air-filled porosity decreases and the tortuosity increases with increasing moisture content, soil moisture induces a two-fold effect on constraining diffusive flow of gases (noting that the gas diffusivity in water is a fourorder-of-magnitude slower process than that in air) thus making $D_{\mathrm{p}} / D_{0}$ a strongly moisture-dependent parameter (Hamamoto, Moldrup, Kawamoto, \& Komatsu, 2009; Moldrup et al., 2000). The soil-water characteristic (SWC), a functional relationship between the soil matric suction $(-\psi, \mathrm{kPa})$ and the corresponding moisture content $\left(\theta, \mathrm{cm}^{3}\right.$ $\left.\mathrm{cm}^{-3}\right)$, gives useful information on soil moisture retention in response to dynamic changes of infiltration and groundwater subsidence. Both $D_{\mathrm{p}} / D_{0}$ and SWC are controlled by the subsurface physical conditions (e.g., texture and structure of the porous system, organic matter content). Previous studies have concluded that both SWC and $D_{\mathrm{p}} / D_{0}$ are strongly linked to the soil texture, a descriptor for the size distribution of particles, thereby making gas emissions also largely particle size-dependent (Arthur, Moldrup, Schjønning, \& de Jonge, 2012; Ding, Sun, \& Huang, 2018). Particle size alters porosity and pore size distribution, which, in turn, affects transport and retention characteristics of soilwater and soil-gas. The amount of diffusive soil-gas flux, as explained by Fick's law, is linearly related to the gas diffusivity and concentration gradient, which makes $D_{\mathrm{p}} / D_{0}$ an important predictor of soil-gas fluxes (Balaine, Clough, Beare, Thomas, \& Menken, 2016).

In this study, we characterized water retention and gas transport properties in the "soil-like" fraction of aged MSW sampled at 2.5-5 m depth from a Sri Lankan open dumpsite. The "soil-like" fractions were proportioned into three groups based on particle size $(0-4.75,4.75-9.5$, and 9.5$25 \mathrm{~mm}$ ) to investigate the effect of particle size on gas transport processes. Based on the existing, modified and newly developed parametric functions, we parameterized the measured properties of soil-water characteristics and $D_{\mathrm{p}} / D_{0}$, and thereby investigated their integrated behavior linking to the particle size. We further investigated simulated methane concentration profiles in differently sized particles based on TOUGH2 numerical package (Pruess, Oldenburg, \& Moridis, 1999) for multiphase (gaseous and liquid) transport of multi-component mixture of gases (methane and air) and water vapor.

\section{2 | PARAMETRIC FUNCTIONS AND NUMERICAL SIMULATIONS}

\section{1 | Particle size distribution (PSD)}

The classical Rosin and Rammler (1933) distribution function correlates the weight passing percentage $P(\%)$ with the corresponding particle size $(x)$ as follows:

$$
P(\%)=100\left\{1-\exp \left[-\left(\frac{x}{D_{63}}\right)^{\beta}\right]\right\}
$$

where $D_{63}(\mathrm{~mm})$ is the particle size corresponding to $63 \%$ finer and $\beta$ (dimensionless) is an adjustable model parameter which represents the spread of the distribution such that a larger value of $\beta$ implies a poor gradation and vice versa. We modified the Equation (1) to obtain a more meaningful relationship replacing $D_{63}$ with $D_{50}$, the mean particle size, as follows:

$$
P(x)=100\left\{1-\exp \left[-\ln (2)\left(\frac{x}{D_{50}}\right)^{\beta}\right]\right\}
$$




\section{2 | Soil-water characteristic (SWC)}

We invoked the van Genuchten (1980) multi-parametric water retention function for water characteristic in unimodal pore distribution medium as follows:

$$
\theta(\psi)=\theta_{\mathrm{r}}+\left(\theta_{\mathrm{s}}-\theta_{\mathrm{r}}\right)\left(\frac{1}{1+\left|\alpha_{i} \psi\right|^{n_{i}}}\right)^{m_{i}}
$$

The aggregated soil media, however, is characterized by two-pore regions: inter-aggregate where pores associate between the aggregate, and intra-aggregate where pores associate inside the aggregate. The Durner (1994) generalized the van Genuchten model (1980) by algebraically superimposing two pore domains for the media which exhibits bimodal (two regions) pore size distribution to obtain a continuous relationship between capillary suction $(\psi)$ and the volumetric water content $(\theta)$. Durner (1994) bimodal model can be presented as:

$$
\begin{aligned}
\theta(\psi)= & \theta_{\mathrm{r}}+\left(\theta_{\mathrm{s}}-\theta_{\mathrm{r}}\right)\left[w\left(\frac{1}{1+\left|\alpha_{1} \psi\right|^{n_{1}}}\right)^{m_{1}}\right. \\
& \left.+(1-w)\left(\frac{1}{1+\left|\alpha_{2} \psi\right|^{n_{2}}}\right)^{m_{2}}\right]
\end{aligned}
$$

where $\theta\left(\mathrm{cm}^{3} \mathrm{~cm}^{-3}\right)$ is the volumetric water content; $\psi(\mathrm{cm})$ is the matric potential; $\theta_{\mathrm{s}}\left(\mathrm{cm}^{3} \mathrm{~cm}^{-3}\right)$ and $\theta_{\mathrm{r}}$ $\left(\mathrm{cm}^{3} \mathrm{~cm}^{-3}\right)$ are the saturated and residual water contents, respectively; $w$ is the weighing factor (model parameter to numerically distinguish the two-regions); $\alpha_{1}$ and $\alpha_{2}$ are the model scaling factors $\left(\mathrm{cm}^{-1}\right)$; and $n_{1}, n_{2}, m_{1}$ and $m_{2}$ are the model shape factors. The shape factor $m$ can be directly linked to $n\left(m_{1}=1-1 / \mathrm{n}_{1}, m_{2}=1-1 / \mathrm{n}_{2}\right)$. The subscripts 1 and 2 represent the two regions of the pore size distribution inter-aggregate region and intra-aggregate region, respectively.

Soil moisture measurements for the SWC were carried out using the $\mathrm{EC}_{2} \mathrm{O}$ EC-5 soil moisture sensors. Empirical two-point $\alpha$ mixing model (Sakaki, Limsuwat, Smits, \& Illangasekare, 2008) was used to convert the sensorrecorded ADC (dimensionless analog-to-digital converter) counts to $\theta\left(\mathrm{cm}^{3} \mathrm{~cm}^{-3}\right)$ as follows:

$$
\theta=\left(\frac{\mathrm{ADC}_{\theta}^{\alpha}-\mathrm{ADC}_{\mathrm{dry}}^{\alpha}}{\mathrm{ADC}_{\mathrm{sat}}^{\alpha}-\mathrm{ADC}_{\mathrm{dry}}^{\alpha}}\right) \Phi
$$

where $\alpha$ is the model coefficient; $\mathrm{ADC}_{\mathrm{dry}}$ and $\mathrm{ADC}_{\mathrm{sat}}$ are the ADC counts corresponding to the soil at dry and saturation conditions, respectively; and $\Phi\left(\mathrm{cm}^{3} \mathrm{~cm}^{-3}\right)$ is the total porosity.

\section{3 | Soil-gas diffusivity $\left(D_{\mathrm{p}} / D_{0}\right)$}

We used a recently-developed two-region gas diffusivity function (Shanujah et al., 2019) based on the previous models (e.g., Chamindu Deepagoda et al., 2012; Moldrup, Olesen, Yoshikawa, Komatsu, \& Rolston, 2005; Resurreccion et al., 2007) to account for the distinct inter and intra-aggregate pore regions in the measured $D_{\mathrm{p}} / D_{0}$ data, considering the cases where measured data were not sufficiently available in the wet region. The new model accounts for a percolation threshold $\left(\varepsilon_{\mathrm{p}}\right)$ which can be attributed to the pronounced water blockage effect typically observed for porous media with large aggregates. Diffusivity remains indistinguishable (or comparable with diffusivity through liquid water) within the air-filled porosity below the percolation threshold. Thus, the new model takes the form of:

Region 1: inter-aggregate pore region

$$
\frac{D_{\mathrm{p}}}{D_{0}}=\frac{\alpha_{1}}{\left(w-\varepsilon_{\mathrm{p}}\right)^{\beta_{1}}}\left[\frac{\varepsilon-\varepsilon_{\mathrm{p}}}{\Phi}\right]^{\beta_{1}} \quad \varepsilon<w \Phi
$$

Region 2: intra-aggregate pore region

$$
\frac{D_{\mathrm{p}}}{D_{0}}=\alpha_{1}+\frac{\alpha_{2}}{(1-w)^{\beta_{2}}}\left[\frac{\varepsilon-w \Phi}{\Phi}\right]^{\beta_{2}} \quad \varepsilon<(1-w) \Phi
$$

where

$$
\alpha_{1}=\left|\frac{D_{\mathrm{p}}}{D_{0}}\right|_{\varepsilon=w \Phi} \quad \alpha_{2}=\left|\frac{D_{\mathrm{p}}}{D_{0}}\right|_{\varepsilon=(1-w) \Phi}
$$

and $w$ is the weighing factor (model parameter to numerically distinguish the two pore regions); $\varepsilon_{\mathrm{p}}\left(\mathrm{cm}^{3} \mathrm{~cm}^{-3}\right)$ is the gas percolation threshold below which gas diffusion ceases due to interconnected water films around the particles; and $\beta$ is the shape factor. The subscripts 1 and 2 indicate region 1 and region 2 , respectively.

All the factors of the models were estimated using the nonlinear, curve-fitting routine SOLVER in MS Excel (Wraith \& Or, 1998).

\subsection{Fate and transport of methane in subsurface}

The governing equations involved in this numerical simulation of multiphase, multi-component landfill gas migration under density-dependent, non-isothermal conditions are presented in the Table 1 (note that parameters related to the equations are listed in the APPENDIX). 
TA B L E 1 Governing equations pertinent to this study as solved in TOUGH2-EOS7CA. See APPENDIX for description of parameters

\begin{tabular}{|c|c|}
\hline Description & Equation \\
\hline Conservation of mass and energy & $\frac{d}{d t} \int_{V_{n}} M^{K} d V=\int_{\Gamma_{n}} \mathbf{F}^{K} \cdot \mathbf{n} d \Gamma+\int_{V_{n}} q_{v}{ }^{K} d V$ \\
\hline Mass accumulation & $M^{\kappa}=\phi \sum_{\beta} S_{\beta} \rho_{\beta} X_{\beta}^{\kappa}$ \\
\hline Phase flux & $\mathbf{F}_{\beta}=-\mathbf{k} \frac{k_{r \beta} \rho_{\beta}}{\mu_{\beta}}\left(\nabla P_{\beta}-\rho_{\beta} \mathbf{g}\right)$ \\
\hline Component flux & $\mathbf{F}_{a d v}^{\kappa}=\sum_{\beta} X_{\beta}^{\kappa} \mathbf{F}_{\beta}$ \\
\hline Molecular diffusion & $F_{d i f}^{\kappa}=-\phi \tau \rho_{\beta} D_{\beta}^{k} \nabla X_{\beta}^{k} ; D_{\beta}^{k}(\mathrm{~T})=D_{\beta}^{k}\left(\mathrm{~T}_{o}\right)\left[\frac{\mathrm{T}+273.15}{273.15}\right] \mathrm{T}_{\mathrm{D}}$ \\
\hline Relative permeability(van Genuchten, 1980) & 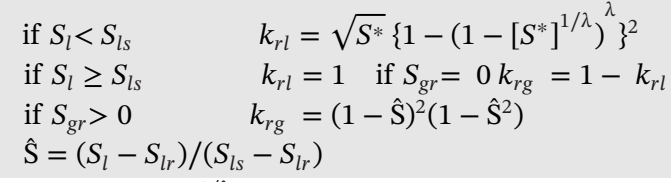 \\
\hline Capillary pressure(van Genuchten, 1980 & $\begin{array}{l}P c=P o\left(\left[S^{*}\right]^{-1 / \lambda}-1\right)^{1-\lambda} \\
\text { subject to }-P_{\max } \leq P c \leq 0\end{array}$ \\
\hline Henry’s law & $P_{g}^{\kappa}=K_{H} x_{w}$ \\
\hline
\end{tabular}

\section{3 | MATERIALS AND METHODS}

\section{1 | Sampling of solid waste}

The waste materials were extracted at a depth of 2.5$5 \mathrm{~m}$ below the surface from an old Municipal Solid Waste (MSW) open dump disposal site at Kurunagala $\left(7^{\circ} 29^{\prime} 10.68^{\prime \prime} \mathrm{N}, 80^{\circ} 21^{\prime} 44.28^{\prime \prime} \mathrm{E}\right)$, Sri Lanka. This is one of the largest and oldest waste disposal sites in the North Western Province of Sri Lanka. The available records revealed that the dumpsite first started its operations in 1921. Average waste collection, within a disposal area of 12.5 acres $\left(\sim 50,500 \mathrm{~m}^{2}\right)$, is about $55 \mathrm{MT} \mathrm{d}^{-1}$. Three suitable locations of an old yard of this dumpsite were excavated with approximate sizes of $3.0 \mathrm{~m}$ (length) by $3.0 \mathrm{~m}$ (width) by $2.5 \mathrm{~m}$ (depth) using a crawler excavator. The excavation was continued until the depth of the pit reached $5 \mathrm{~m}$ below the surface. Waste materials, $190 \mathrm{~kg}$ in total, were collected from $2.5-5 \mathrm{~m}$ depth profile, packed in three polythene bags, and transferred to the laboratory for characterization. The gravimetric moisture content of the bulk sample, measured in triplicates immediately upon receiving, varied between $19-25 \%$ with an average of $23 \%$. The samples were then airdried for two weeks to enable separation of different materials that were tightly held by water. The samples were then screened by $50-\mathrm{mm}$ and $25-\mathrm{mm}$ sieves, respectively and the materials were manually separated into different categories as given in Table 2 .

Table 2 shows the average weight percentage of different particle components collected at the depth of 2.5-5 m. Note that nearly $0.55-0.60 \mathrm{w} / \mathrm{w}$ of the collected waste constituted the "soil-like" fraction of which maximum particle size was below $25 \mathrm{~mm}$. Solid particles $>25 \mathrm{~mm}$ were mostly stones which did not represent the "soil-like" fraction. The plastic, metal, stones, paper, glass, textile, and other inerts
TA B L E 2 Composition of aged waste by average weight percentages

\begin{tabular}{|l|l|}
\hline Components of aged waste & Average $(\%, \mathbf{w} / \mathbf{w})$ \\
\hline Plastic (Hard) & 2.7 \\
\hline Plastic (Soft) & 14.3 \\
\hline Metal & 0.5 \\
\hline Stones $(\mathrm{X}>4.00 \mathrm{~mm})$ & 8.7 \\
\hline Paper & 0.1 \\
\hline Textile & 4.2 \\
\hline Glass and Ceramic & 1.6 \\
\hline Rubber & 0.6 \\
\hline Other inert (Organic) & 3.1 \\
\hline Other inert (inorganic) & 6.3 \\
\hline "soil-like” fraction $(0-25 \mathrm{~mm})$ & 57.8 \\
\hline
\end{tabular}

were removed by hand to separate "soil-like" fraction from the bulk waste. The "soil-like" fraction $(<25 \mathrm{~mm})$ was further sieved using two corresponding sieve sizes $(9.5 \mathrm{~mm}$ and $4.75 \mathrm{~mm}$ ) to make the particles into three different size fractions which are hereafter referred to as Fraction $1(0-4.75 \mathrm{~mm})$, Fraction $2(4.75-9.5 \mathrm{~mm})$, and Fraction $3(9.5-25 \mathrm{~mm})$. The "soil-like" fraction was dominated by the Fraction $3(0.61 \mathrm{w} / \mathrm{w})$, followed by the Fraction $2(0.22 \mathrm{w} / \mathrm{w})$ and the Fraction $1(0.17 \mathrm{w} / \mathrm{w})$, respectively. Notably, larger aggregates were not crushed to obtain smaller aggregates; rather the natural aggregates of different sizes were collected by sieving. Figure 1 shows the textural contrast of the three fractions. We first characterized the proportioned fractions with respect to grain-size distribution. Mechanical and manual sieving were used to derive the particle size distribution for Fraction 2 and Fraction 3 whereas both mechanical sieving and hydrometer (for the fraction passing the $0.75-\mathrm{mm}$ sieve) methods 
(a)

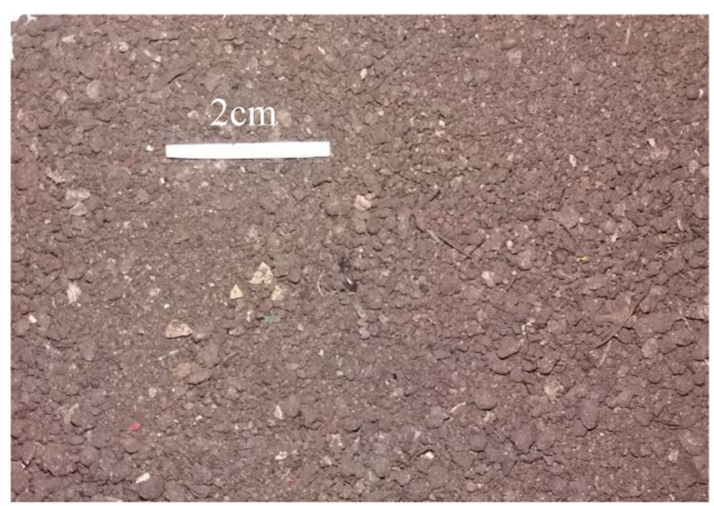

(b)

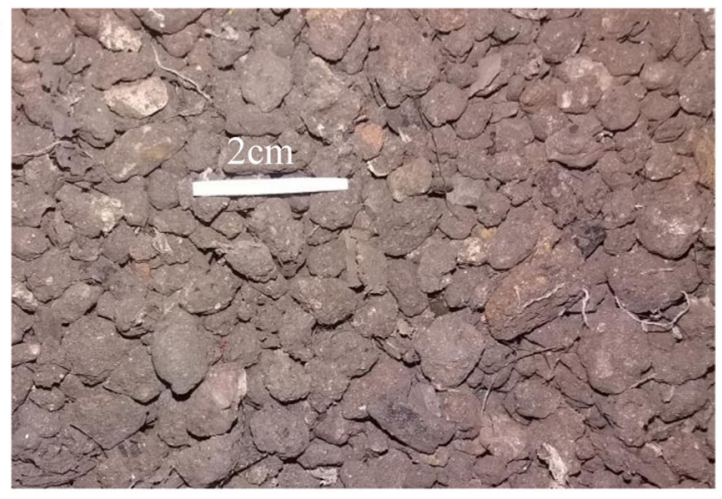

(c)

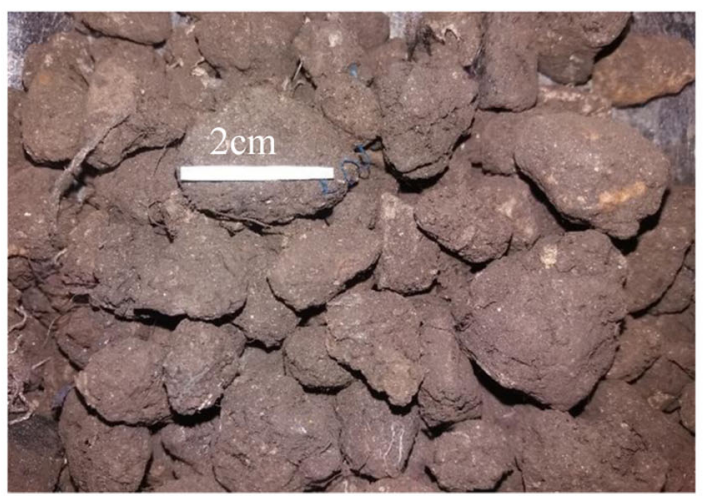

F I G U R E 1 Textural contrast of Fraction 1 (0-4.75 mm) (a), Fraction 2(4.75-9.5 mm) (b) and Fraction 3 (9.5-25 mm) (c)

TA B LE 3 Physical properties of the investigated "soil-like" fraction in the aged MSW

\begin{tabular}{llllllll} 
Fractions & $\begin{array}{l}\text { Particle size } \\
\text { range }\end{array}$ & $\mathbf{D}_{\mathbf{5 0}}{ }^{\mathrm{a}}$ & Bulk density & $\begin{array}{l}\text { Total } \\
\text { porosity }\end{array}$ & $\begin{array}{l}\text { Particle } \\
\text { density }\end{array}$ & $\begin{array}{l}\text { Organic } \\
\text { content }\end{array}$ & $\begin{array}{l}\text { Hydraulic } \\
\text { conductivity }\end{array}$ \\
\hline 1 & $\mathrm{~mm}$ & $\mathrm{~mm}$ & $\mathrm{~g} \mathrm{~cm}^{-3}$ & $\mathrm{~cm}^{3} \mathrm{~cm}^{-3}$ & $\mathrm{~g} \mathrm{~cm}^{-3}$ & $\mathrm{~kg} \mathrm{~kg}^{-1}$ & $\mathrm{~cm} \mathrm{~s}^{-1}$ \\
\hline 2 & $0-4.75$ & 0.78 & 1.025 & 0.541 & $2.40(0.018)$ & $0.19(0.011)$ & $0.0011^{\mathrm{c}}$ \\
\hline 3 & $4.75-9.5$ & 6.14 & 0.973 & 0.558 & $2.45(0.087)$ & $0.20(0.014)$ & $0.013^{\mathrm{d}}$ \\
\hline
\end{tabular}

a Taken from the parameterized particle size gradation curve

${ }^{\mathrm{b}}$ Standard deviation of the results are given in parentheses

${ }^{\mathrm{c}}$ Measured by falling head permeability test method

${ }^{\mathrm{d}}$ Measured by constant head permeability test method

were used for the Fraction 1. Furthermore, we measured the soil-water retention (using Tempe cell apparatus), and gas-diffusivity (using one-chamber diffusion apparatus), saturated hydraulic conductivity and permeability (using constant head or falling head apparatus), and soil organic carbon content (based on loss-on-ignition method) of all three fractions separately. Table 3 represents the physical properties of all the groups of the "soil-like" fraction.

\section{2 | Soil-water characteristic (SWC)}

A Tempe cell apparatus (Smits, Sakaki, Howinton, Peters, \& Illangasekara, 2013) consisting of a Plexiglas wall cell
(8.8 cm outer diameter, $0.6 \mathrm{~cm}$ wall thickness, $9.0 \mathrm{~cm}$ height) outfitted with a large porous cup $(1.0 \mathrm{~cm}$ diameter, $7.2 \mathrm{~cm}$ length, $51 \mathrm{kPa}$ air-entry value, Soil Moisture Equipment) was used to measure the SWC. The cell was hydraulically connected to a $200-\mathrm{cm}$ tall water reservoir to regulate the matric suction. The samples were subjected to 30 levels of matric potential $(\psi)$ between 0 to $-17 \mathrm{kPa}$ by sequential draining. At each corresponding suction level, the water level in the reservoir was maintained constant for 2 days to ensure the gravity-capillary equilibrium within the sample before moving to the next suction level. Further details of the measurement method can be found in Wallen et al. (2013) who also shows a schematic of the 
experimental apparatus. To measure soil moisture at each matric suction, a dielectric soil moisture sensor (ECH2O EC-5, 5.5-cm prong length, 70-MHz measurement frequency, Decagon Devices) was installed within the cell in such a way that the long axis of the sensor was horizontal and the flat plan was vertical. The sensor was calibrated following a method developed by Sakaki et al. (2008). The soil was first dry-packed into the cell and the corresponding $\mathrm{ADC}$ count $\left(\mathrm{ADC}_{\mathrm{dry}}\right)$ was taken. Next, each fraction was wet-packed in the cell with the water level kept always above the soil surface being packed. The water level of the reservoir was initially set to the top surface of the cell, and $\mathrm{ADC}$ count in fully saturated condition $\left(\mathrm{ADC}_{\mathrm{sat}}\right)$ was taken. Subsequently, the water level of the reservoir was systematically lowered to the intended suction levels and the corresponding ADC count was taken at each suction levels. The ADC counts were used to calculate the volumetric water content at each metric potential by using the two-point $\alpha$-mixing model (Equation 5).

\section{3 | Soil-gas diffusivity $\left(D_{\mathrm{p}} / D_{0}\right)$}

We used a one-chamber diffusion apparatus to measure the diffusion coefficient (Currie, 1960). An air-tight chamber made with a $10-\mathrm{mm}$ thick PVC tube was used as the diffusion apparatus (Chamindu Deepagoda et al., 2015). All three size fractions were packed in $100-\mathrm{cm}^{3}$ annular cores by keeping the packing energy constant. The soil cores were first attached to a $5-\mathrm{mm}$ diameter rubber $\mathrm{O}$ ring which is inserted into a groove at the top of the tube in order to facilitate the positioning of the sample during measurement. The chamber was flushed with nitrogen to remove all oxygen. An oxygen sensor (KE-12, Figaro Engineering Inc., Osaka, Japan) mounted at the chamber wall continuously monitored changes in oxygen concentration inside the chamber. When the chamber reached zero oxygen concentration, the sample was open to allow atmospheric $\mathrm{O}_{2}$ to diffuse into the chamber. Measurements were initiated at the fully saturated condition, and continued for several air-dry steps. Oxygen concentration data were used to calculate soil-gas diffusivity $\left(D_{\mathrm{p}} / D_{0}\right)$ by following the Currie (1960) method, and $D_{0}$ (oxygen diffusion coefficient in free air) is taken as $0.205 \mathrm{~cm}^{2}$ air s${ }^{-1}$ at $20{ }^{\circ} \mathrm{C}$.

\section{4 $\quad$ Numerical simulation}

Subsurface methane concentration profiles were simulated using a multiphase transport simulator, TOUGH2 with the equation of state module, EOS7CA (Oldenburg,
2015; Pruess et al., 1999). TOUGH2-EOS7CA can simulate subsurface flow and transport of liquid and gas phases (i.e., $\mathrm{H}_{2} \mathrm{O}$, brine, non-condensable gas (e.g., $\mathrm{CH}_{4}$ ), gas tracer, and air) under isothermal or non-isothermal conditions. TOUGH2-EOS7CA uses thermodynamic properties in real gas mixtures (i.e., density, enthalpy departure and viscosity) which can be calculated using the PengRobinson equation of state module (Peng \& Robinson, 1976). Gas diffusion in this simulation is modelled using a temperature-dependent Fickian molecular diffusion coefficient. Henry's law models dissolution of gaseous methane in the aqueous phase, with Henry's coefficients, estimated using the method explained by Cramer (1982). Previous studies have evidenced a good agreement with measured methane concentrations and simulations from TOUGH2EOS7CA under different subsurface soil conditions (e.g., Chamindu Deepagoda, Smits, \& Oldenburg, 2016), hence proved to be promising numerical tool to estimate subsurface methane migration in the absence of direct concentration measurements.

A 2-D Cartesian computational domain (width $5 \mathrm{~m}$, height $5 \mathrm{~m}$ ) was discretized into 400 porous elements to simulate field subsurface methane concentration with differing particle size. The height of the domain was selected to indicate the sampling depth. The left, right, and the bottom boundaries of the domain were set as no-gas flow condition (Neumann-type) and adiabatic for heat transport, whereas the top boundary is considered as an open boundary for both gas and heat flow. All bottom elements were set to $60{ }^{\circ} \mathrm{C}$ to mimic the average temperature at $5 \mathrm{~m}$ depth of a typical open disposal site (Aran et al., 1999; Townsend, Miller, Lee, \& Earle, 1996). The bottom mid four elements were set as a methane area source (1 $\mathrm{m} \times 1 \mathrm{~m})$, and the methane was emitted with a mass flow rate of $3.84 \times 10^{-7} \mathrm{~kg} \mathrm{~s}^{-1}(0.6 \mathrm{v} / \mathrm{v}$ methane and $0.4 \mathrm{v} / \mathrm{v}$ air), which was estimated from the IPCC (2006) waste model. We assumed that homogeneous and isotropic conditions with respect to physical properties and transport parameters prevail across the entire domain. Also, the simulations assumed no (or indistinguishably small) uptake of methane due to oxidation to ensure a conservative simulation. Simulations were carried out for two moisture conditions: near-dry (i.e., $\theta=\theta_{\mathrm{r}}$ ) and half-saturated $(\theta=0.5 \Phi)$ throughout the domain. Note that a small gradient in the saturation (see Figure 2 has resulted due to the gravitational movement of water. A pre-simulation was first performed to obtain the gravity-capillary equilibrium within the domain before applying the methane flow. Figure 2 shows the discretized computational domain for methane migration simulations at partially saturated condition and the temperature variation across the depth. 
(a)

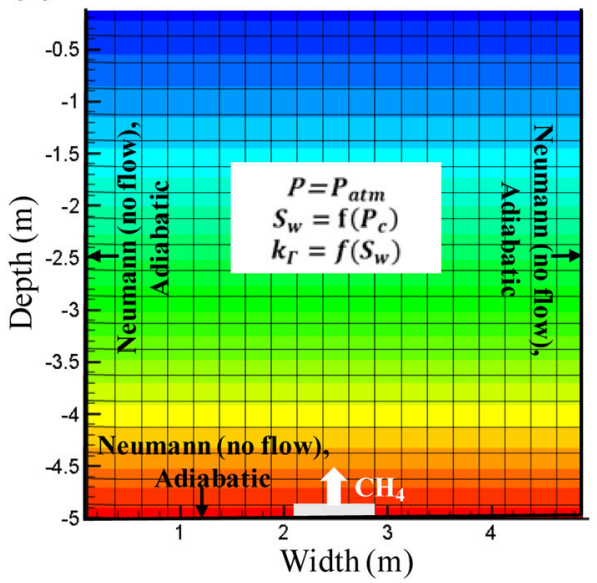

(b)

Liquid Saturation

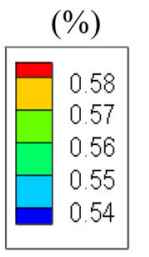

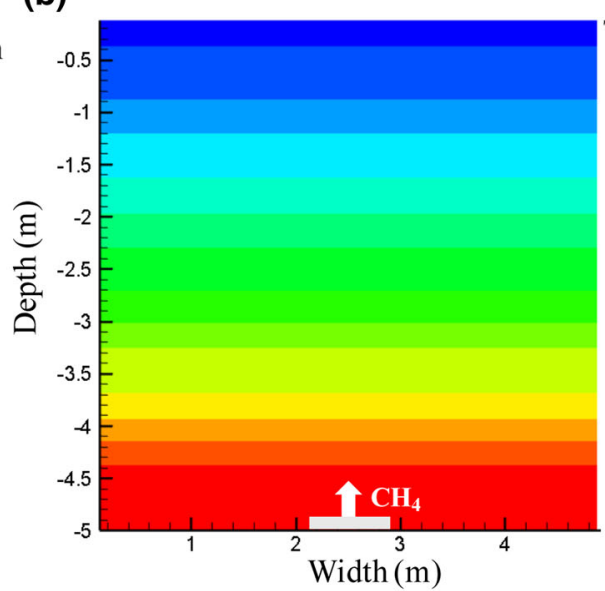

Temperature $\left({ }^{\circ} \mathrm{C}\right)$

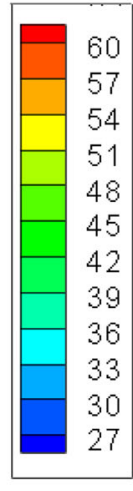

F I G U R E 2 Discretized 2-D computational domains for methane migration simulations. (a) Saturation gradient and initial and boundary conditions where $S_{\mathrm{w}}$ is the water phase saturation, $P_{\mathrm{c}}$ is the capillary pressure, and $k_{\Gamma}$ is the relative permeability. (b) Temperature profile along the depth. Location of the methane source is also shown in this figure. The simulated area source (1 $\mathrm{m}$ by $1 \mathrm{~m})$ of methane is illustrated in both (a) and (b)

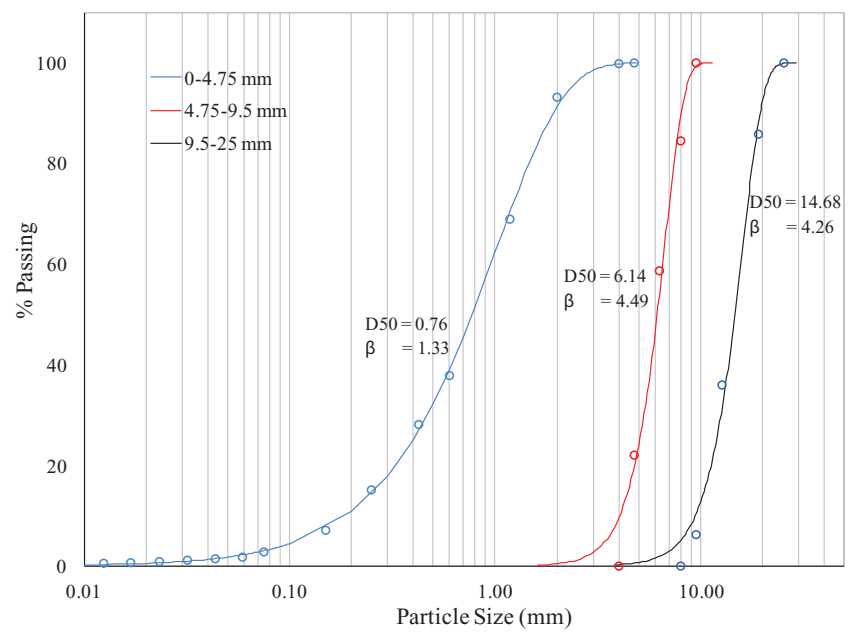

F I G U R E 3 Measured particle size distribution of three size fraction (denoted by differently colored circles), modified and parameterized Rosin-Rammler (1933) distribution function (Equation 2), denoted by differently colored solid lines. Note that the particle size is plotted on log-scale

\section{4 | RESULTS AND DISCUSSION}

\section{1 | Particle-size distribution (PSD)}

Figure 3 shows the particle size distribution of all three size fractions as also described by the modified and parameterized Rosin-Rammler (1993) model (Equation 2). Note that the abscissa was plotted on a logarithmic scale to encompass particle diameters of several orders of magnitude. Noticeably, a smooth curve obtained in Fraction 1 indi- cates a well-graded particle size distribution (Coefficient of uniformity, $\mathrm{C}_{\mathrm{u}}=5.1$ ) whereas Fractions 2 and 3 exhibited poorly graded (or better-sorted) particle size distributions with $\mathrm{C}_{\mathrm{u}}=1.61$ and 1.63 , respectively. This is also demonstrated by the Rosin-Rammler size distribution parameter $\beta$ which indicates larger values for Fraction $2(\beta=4.49)$ and Fraction $3(\beta=4.26)$ as compared to the Fraction 1 $(\beta=1.33)$. The mean particle size $\left(D_{50}\right)$ range (see Table 3$)$ suggests a marked difference in "soil-like" fractions, and hence different soil-solid phase and particle-pore network configuration that facilitates gas transport and water retention properties.

\subsection{Soil-water characteristic (SWC)}

The SWC for all three size fractions are shown in Figure 4 together with the best-fit parameterized Durner (1994) model (Equation 4). Importantly, all fractions exhibited a bimodal behavior, commonly observed for dual porosity media with distinct intra-aggregate and inter-aggregate pore size distributions. Note the systematic decline in saturated moisture content $\left(\theta_{\mathrm{s}}\right)$ with decreasing particle size, due to the decrease in total porosity. However, the particle size effect in SWC becomes less evident at low matrix potentials. It is clearly seen that all fractions have the same and notably, small air-entry pressure/bubbling pressure $\left(P_{\mathrm{b}}=-1.75 \mathrm{kPa}\right.$ or $\left.\mathrm{pF}=1.24\right)$ requirement to initiate desaturation. This small air-entry value indicates rapid gravity drainage of the inter-aggregate pores within a narrow matric potential range. Note that the volume of water 


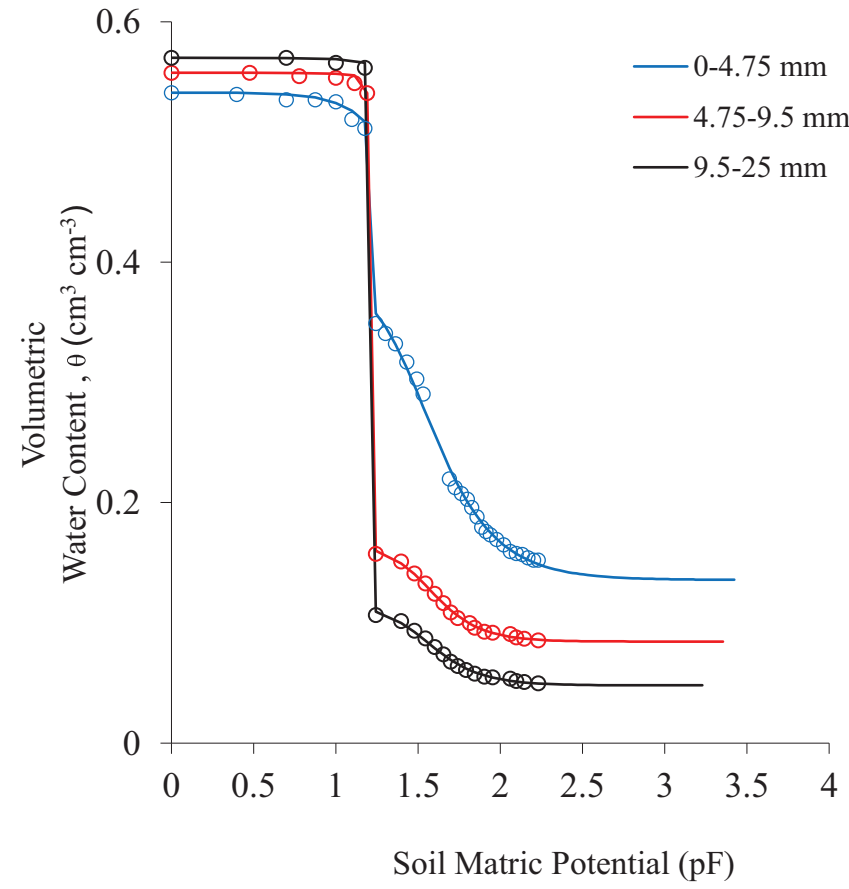

F I G U R E 4 Volumetric soil-water content $\left(\theta, \mathrm{cm}^{3} \mathrm{~cm}^{-3}\right)$ as a function of soil metric potential $(\mathrm{pF})$ for three size fractions (denoted by differently colored circles) together with parameterized Durner (1994) bimodal function (Equation 4, denoted by differently colored solid lines)

retained before the air-entry pressure is low in Fraction 1 due to the smaller total porosity as compared to the Fraction 2 and Fraction 3. However, this trend has reversed with the rapid desaturation after the air-entry potential is exceeded, making more water available in the smaller fraction as compared to the two larger fractions. This is due to the presence of high capillary pores in the smaller fraction which retain more water, as compared to the gravity pores dominated in the two large fractions. Further, the difference in volumetric water in different size fractions diminishes at higher matric suctions (above $\mathrm{pF}=2$ ) because water is held as thin water films around solid particles by adsorptive forces rather than occupying the pores. In fact, at higher matric suctions, moisture retention is predominantly texture-controlled rather than structure controlled, making higher water-holding capacity with decreasing particle size. The Durner (1994) bimodal (Equation 4) provided a very good description of two distinct pore regions of aggregates as shown by the solid lines.

\subsection{Soil-gas diffusivity $\left(D_{\mathrm{p}} / D_{0}\right)$}

Gas-diffusivity of all three size fractions plotted against air-filled porosity is presented in Figure 5a together with the predictions from the proposed gas diffusivity model
(Equations $6 \&$ 7). Interestingly, $D_{\mathrm{p}} / D_{0}$ behavior also implies strong bimodal characteristics with distinct intraaggregate and inter-aggregate pore regions. As the applied matric suction exceeds the air entry value, bigger pores start draining first allowing air to enter the sample. Fraction 1, consisting of smaller number of large pores, showed a systematic increase in air content as the matric suction increases, thus giving a series of measurements over the entire air-filled porosities. However, in the Fractions 2 and 3 where larger pores dominate, measurements could not be made at smaller air-filled porosities, as the pores were already drained immediately after the air-entry potential is exceeded. The Fraction 2 and Fraction 3, therefore, showed a high percolation threshold for gas diffusivity. The percolation threshold in this case is an air content region which showed no distinguishable diffusivity due to the pronounced water blockage. The gas percolation threshold decreased with decreasing particle size as also evidenced in the literature (Chamindu Deepagoda et al., 2012). Note also the decreasing intra-aggregate pore space with increasing particle size, which is in line with the observation from SWC described above. Within the intra-aggregate region, all fractions showed a linear increase in gas diffusivity with nearly the same gradient $\left(D_{\mathrm{p}} / D_{0}=0.21 \varepsilon\right)$. The new tworegion $D_{\mathrm{p}} / D_{0}$ model, which accounts for a gas percolation threshold (Equation 6), described the gas diffusivity behavior in the inter-aggregate region and hence proved to be a useful tool to estimate $D_{\mathrm{p}} / D_{0}$ descriptively in largeaggregated media with distinct gas percolation thresholds. The model-derived gas percolation threshold values for the Fractions 1, 2, and 3 are $0,0.1$, and $0.2 \mathrm{~cm}^{3} \mathrm{~cm}^{-3}$, respectively. The presence of a large percolation threshold essentially indicates that the aeration conditions cannot be represented by the air-filled porosity per se, as the available air-filled pores may be isolated by water bridges surrounding them, thus creating a large tortuosity for gas migration. In this regard, $D_{\mathrm{p}} / D_{0}$ is a good measure of the potential for gas migration as it accounts both air-filled pore space and tortuosity/connectivity of the functional gaseous phase.

Figure 5b graphically illustrates the interrelation between the mean fraction size, diffusivity and volumetric water content in a two-dimensional plot. The color contours indicate the corresponding $D_{\mathrm{p}} / D_{0}$. The effect of pronounced percolation threshold on gas diffusivity with increasing particle size can be clearly seen (with a large blue-colored area). Although diffusivity is generally seen as a nonlinear particle size-dependent, it is interesting to see that $D_{\mathrm{p}} / D_{0}$ remained largely the same at a volumetric water content of $\sim 0.22-0.25 \mathrm{~cm}^{3} \mathrm{~cm}^{-3}$ across all size fractions. The plot thus serves as a useful tool for quick estimation of $D_{\mathrm{p}} / D_{0}$ for a known pair of particle size and volumetric water content in the absence of direct diffusivity measurements. 
(a)

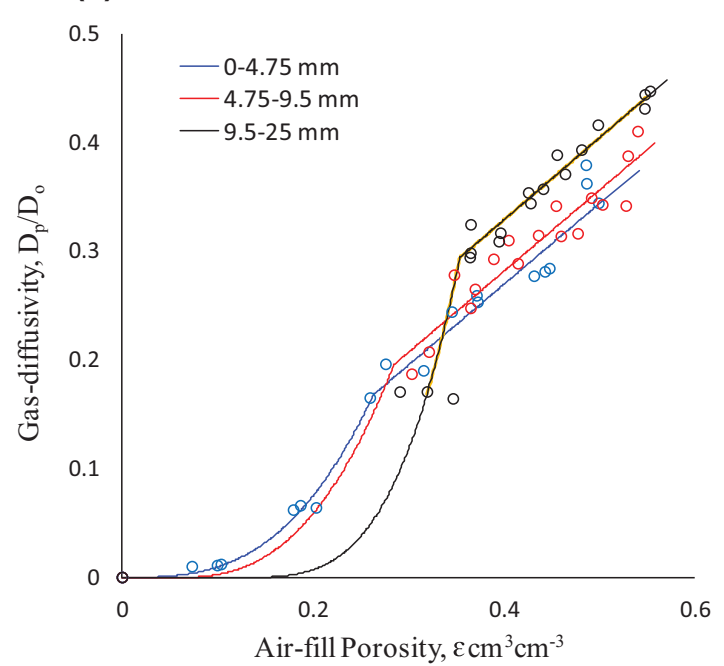

(b)

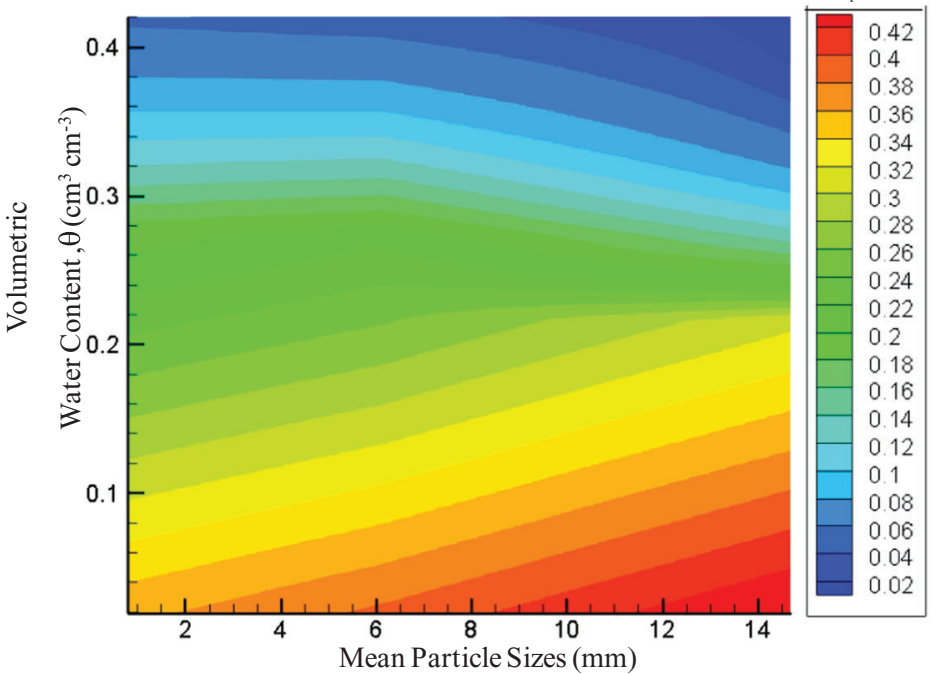

F I G U RE 5 (a) Soil-gas diffusivity, $D_{\mathrm{p}} / D_{0}$, as a function of air-fill porosity for three different size fractions (shown in differently colored circles) together with newly established $D_{\mathrm{p}} / D_{0}$ bimodal function (Equations 6 and 7, shown in differently colored lines). (b) Two-dimensional representation of the relationship between volumetric water content $\left(\theta, \mathrm{cm}^{3} \mathrm{~cm}^{-3}\right)$ and diffusivity $\left(D_{\mathrm{p}} / D_{0}\right)$ with varying particle sizes. The color contours show the diffusivity
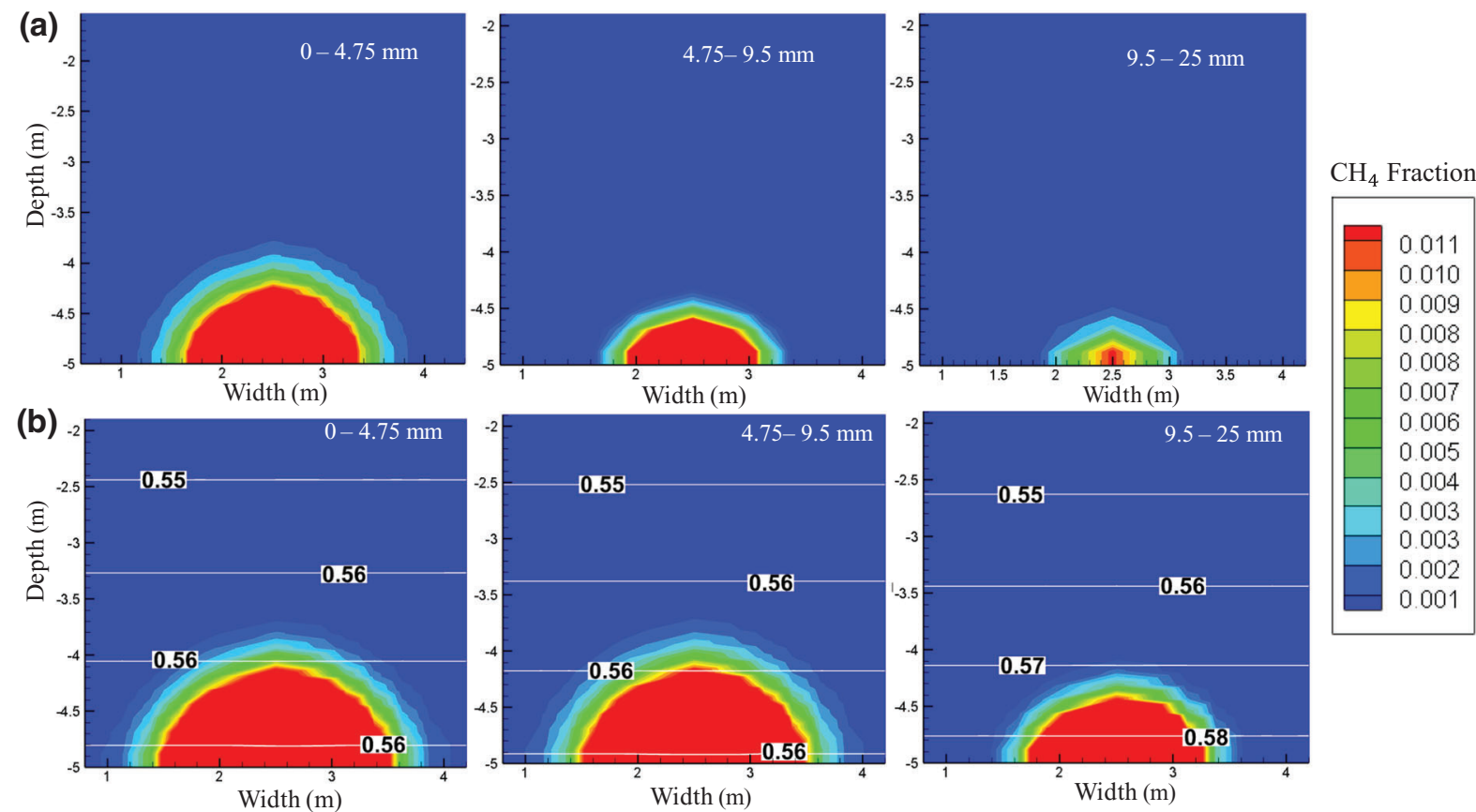

F I G U R E 6 Simulated steady-state methane concentration profiles for all three fractions. (a) At dry condition. (b) At partially saturated condition (50\% saturation). Colors denote the mass fraction of gaseous methane. White colored horizontal lines indicate the saturation contours

\section{4 | Numerical simulations}

Figure 6 shows the steady-state methane concentration profiles for all three fractions at (a) dry condition and (b) half-saturation condition under a known temperature gradient (Figure $2 \mathrm{~b}$ ). Note that the model accounts for a temperature correction on density, viscosity, solubility and gas diffusion coefficient of methane within an advection-diffusion modelling framework. The low density of methane with respect to the air causes density-driven advective flow which preferentially occurs upwards, leading to an upward-bulging methane 
profile as can be seen with all size fractions. The lateral and downward movements, however, are only diffusioncontrolled and diffusive movement is virtually the same in all directions in a given fraction. Notably, high porosity $\left(0.57 \mathrm{~cm}^{3} \mathrm{~cm}^{3}\right)$ combined with low bulk density $\left(0.97 \mathrm{~g} \mathrm{~cm}^{-3}\right)$ in Fraction 3 is highly favourable for gas transport (hence smallest retention within the porous system) which yielded the smallest upward-bulged profile. The lateral migration at dry condition is also most favourable in the Fraction 3 due to the high $D_{\mathrm{p}} / D_{0}$ and permeability (Table 3 ). On the other hand, among the three fractions, Fraction 1 exhibited the largest methane containment, hence the most elevated concentration profile due to the lowest total porosity (associated with the highest density), lowest diffusion coefficient and permeability. As the Figure $6 \mathrm{~b}$ clearly shows, the concentration profiles are more pronounced under half-saturation condition (note the saturation contours in white color) due to the marked water-induced effects on $D_{\mathrm{p}} / D_{0}$ in all directions. Thus, the simulations clearly demonstrate the effect of particle-size-dependant methane migration through waste in a deep landfill subsurface as further controlled by the moisture status.

We emphasize herein that the scope of this study was limited to characterizing the "soil-like" fraction and simulating its potential effects on the fate and transport of methane in deep $(2.5-5 \mathrm{~m})$ landfill subsurface. Diffusivity calculations did not particularly consider the effect of microbial oxygen consumption in order to enable a more conservative analysis. We further ignored the presence of landfill gas constituents in the gaseous phase other than methane (e.g., $\mathrm{CO}_{2}$ ) which may also cause an effect on simulated results. Numerical analysis further presumed that the entire domain occupied the "soil-like" fraction, though other constituents are also available in the observed mixture (Table 2). Therefore, care needs to be taken when comparing the results of this study with field-based measurements since more complex environmental variables in field conditions may cause a marked deviation from the observed results of this study.

\section{5 | CONCLUSIONS}

The effects of particle size in "soil-like" fraction sampled at 2.5-5 m depth from an old Sri Lankan open dump disposal site was examined in relation to their gas transport properties and water-retention characteristics. Measured gas diffusivity $\left(D_{\mathrm{p}} / D_{0}\right)$ and soil-water characteristic (SWC) in selected three size fractions (0-4.75, 4.75-9.5, and 9.5$25 \mathrm{~mm}$ ) showed strong bimodal behavior due to the presence of inter and intra-aggregated pore regions. Further, both $D_{\mathrm{p}} / D_{0}$ and SWC were found to be strongly particle- size dependent, which markedly affected their gas transport behavior. We presented a practical tool for estimating $D_{\mathrm{p}} / D_{0}$ for known particle size and volumetric water content in the absence of direct $D_{\mathrm{p}} / D_{0}$ measurements. Despite large nonlinear variation of $D_{\mathrm{p}} / D_{0}$ with particle size, results showed that the gas-diffusivity remained the same across all fractions at the volumetric water content of $\sim 0.22-0.25 \mathrm{~cm}^{3} \mathrm{~cm}^{-3}$. We used extended, existing and newly developed parametric functions to adequately describe the measured particle-size distribution, bimodal SWC, and bimodal $D_{\mathrm{p}} / D_{0}$ respectively. The methane concentration profiles obtained from a simulated methane source under a predefined temperature gradient showed a marked variation across the three size fractions under dry condition and also more prominently under the halfsaturation condition. The results provide useful implications on methane migration in old dumps where hierarchical development of "soil-like" matter in aged MSW may result in higher gas emissions and large variability with saturation. While the results provided a valuable insight to understand the particle-size-dependent gas transport in aged landfill materials, further experimental and numerical studies which account more complex landfill variables are needed to obtain more realistic outcomes.

\section{ACKNOWLEDGMENTS}

Financial support from Indian-Sri Lankan Inter Governmental Science and Technology Co-operation Programme (Grant no. MTR/TRD/AGR/3/2/17) is gratefully acknowledged. Partial funding from India-Sri Lanka foundation (Grant no. 247/17) is also acknowledged. Any opinion, findings, and conclusions or recommendations expressed herein are those of the authors and do not necessarily reflect the views of those providing technical input or financial support. Trade names are mentioned only for identification purpose and do not constitute endorsement from any party involved in this study.

\section{REFERENCES}

Abreu, A., \& Vilar, O. M. (2017). Influence of composition and degradation on the shear strength of municipal solid waste. Waste Management Journal, 68, 263-274, https://doi.org/10.1016/j.wasman. 2017.05.038

Aran, C., Franck, S., Berroir, G., \& Gisbert, T. (1999). Leachate recirculation by horizontal trenches instrumentation. Paper presented at the Seventh International Waste Management and Landfill Symposium. Sardinia, Cagliari, Italy.

Arthur, E., Moldrup, P., Schjønning, P., \& de Jonge, L. W. (2012). Linking particle and pore size distribution parameters to soil gas transport properties. Soil Science Society of America Journal, 76, 18-27.

Balaine, N., Clough, T. J., Beare, M. H., Thomas, S. M., \& Menken, E. D. (2016). Soil gas diffusivity controls $\mathrm{N}_{2} \mathrm{O}$ and $\mathrm{N}_{2}$ emission and their ratio. Soil Science Society of America Journal, 80, 529-540. 
Barlaz, M. A., Schaefer, D. M., \& Ham, R. K. (1989). Applied Environmental Microbiology, 55(1), 55-65, U.K: Harwell Laboratory, 102.

B1oltze, U., \& de Freitas, M. H. (1995). Monitoring gas emissions from landfill sites. Waste Management Research, 15, 463-476. https://doi. org/10.1177/0734242x9701500503

Bookter, T. J., \& Ham, R.K. (1982). Stabilization of solid waste in landfills. Journal Environmental Engineering, 108(6), 1089-1100.

Burlakovs, J., Kaczala, F., Vincevica-Gaile, Z., Rudovica, V., Orupõld, K., Stapkevica, M., ... Hogland, W. (2016). Mobility of metals and valorization of sorted fine fraction of waste after landfill excavation. Waste Biomass Valoriz, 7, 93-602. https://doi.org/10.1007/ s12649-016-9478-4

Chamindu Deepagoda, T. K. K., Moldrup, P., Jensen, M.P., Jones, S.B., de Jonge, L.W., Schjønning, P., ... Komatsu, T. (2012). Diffusion aspects of designing porous growth media for earth and space soils. Soil Science Society of America Journal, 76, 1564-1578. https://doi. org/10.2136/sssaj2011.0438

Chamindu Deepagoda, T. K. K., \& Elberling, B. (2015). Characterization of diffusivity-based oxygen transport in Arctic organic soil. European Journal of Soil Science, 66, 983-991. https://doi.org/10. 1111/ejss.12293

Chamindu Deepagoda, T. K. K., Smits, K. M., \& Oldenburg, C. M. (2016). Effect of subsurface soil moisture variability and atmospheric conditions on methane gas migration in shallow subsurface. International Journal of Greenhouse Gas Control, 55, 105-117. https://doi.org/10.1016/j.ijggc.2016.10.016

Cheng-liang, Z., Jing-jing, F., Ting-ning, Z., \& Li-ming, R. (2016). Physical, chemical, and engineering properties of landfill stabilized waste. Land Degradation and Development, 28, 1113-1121. https://doi.org/10.1002/ldr.2594

Christophersen, M., \& Kjeldsen, P. (2001). Lateral gas transport in soil adjacent to an old landfill: Factors governing gas migration. Waste Management \& Research, 19, 579-594. https://doi.org/10. 1177/0734242X0101900615

Cossu, R., Motzo, G. M., \& Laudadio, M. (1995). Preliminary study for a landfill mining project in Sardinia. Margherita di Pula, Cagliari, Italy: Proceedings Sardinia Fifth International Waste Management and Landfill Symposium, 841-850.

Cramer, S. D. (1982). The solubility of methane, carbon dioxide, and oxygen in brines from $0^{\circ} \mathrm{C}$ to $300^{\circ} \mathrm{C}$. U.S. Bureau of Mines. Report No. 8706. Washington, D.C.: U.S. Bureau of Mines.

Crawford, J. F., \& Smith, P. G. (1985). Landfill technology. London: Butterworths.

Currie, J. A. (1960). Gaseous diffusion in porous media.1. A nonsteady state method. British Journal of Applied Physics, 11(8), 314317. https://doi.org/10.1088/0508-3443/11/8/302

Danthurebandara, M., Van Passel, S., \& Van Acke, K. (2015). Environmental and economic assessment of "open waste dump" mining in Sri Lanka. Resources Conservation and Recycling, 102, 67-79. https://doi.org/10.1016/j.resconrec.2015.07.004

Ding, F., Sun, W., \& Huang, Y. (2018). Net $\mathrm{N}_{2} \mathrm{O}$ production from soil particle size fractions and its response to changing temperature. Science Total Environ, 650, 97-104. https://doi.org/10.1016/j. scitotenv.2018.08.428

Durner, W. (1994). Hydraulic conductivity estimation for soils with heterogeneous pore structure. Water Resources Research, 30, 211223. https://doi.org/10.1029/93WR02676

Fadel, M. E., Findikakis, A. N., \& Leckie, J. O. (1996). Numerical modelling of generation and transport of gas and heat in landfills model formulation. Waste Management and Research, 14, 483-504. Retrieved from https://doi.org/10.1177/0734242x9601400506

Hamamoto, S., Moldrup, P., Kawamoto, K., \& Komatsu, T. (2009). Effect of particle size and soil compaction on gas transport parameters in variably saturated, sandy soils. Vadose Zone Journal, 8, 986-995.

Herath, G. B. B. 2015. Landfill gas monitoring, a case study from UdaPalatha, Sri Lanka, Colombo, Sri Lanka: International Workshop on Reduction of GHG from Landfills.

Hölzle, I. (2018). Analyzing material flows of landfill mining in a regional context. Journal of Cleaner Production, 207, 317-328.

IPCC. (2006). Guidelines for national greenhouse gas inventories. Eggleston, H. S., Buendia, L., Miwa, K., Ngara, T., \& Tanabe, K., (Eds.), Japan: Prepared by the National Greenhouse Gas Inventories Programme IGES.

Kaartinen, T., Sormunen, K., \& Rintala, J. (2013). Case study on sampling, processing and characterization of landfilled municipal solid waste in the view of landfill mining. Journal of Cleaner Production, 55, 56-66.

Kjeldsen, P. (1996). Landfill gas migration in soil. T. H. Christensen, R. Cossu, \& R. Stegmann (Eds.), London: Land filling of waste, Biogas.

Krook, J., Svensson, N., \& Eklund, M. (2012). Landfill mining: A critical review of two decades of research. Waste Management, 32, 513520. https://doi.org/10.1016/j.wasman.2011.10.015

Kurian, J., Esakku, S., \& Nagendran, R. (2007). Mining compost from dumpsites and bioreactor landfills. International Journal of Environmental Technology and Management, 7, 317-325.

Lelieveld, J., Crutzen, P. J., \& Dentener, F. J. (1998). Changing concentration, lifetime and climate forcing of atmospheric methane. Tellus, 50B, 128-150. https://doi.org/10.1034/j.1600-0889.1998.t011-00002.x

Menikpura, S. N., Gheewala, S. H., \& Bonnet, S. (2012). Sustainability assessment of municipal solid waste management in Sri Lanka: Problems and prospects. Journal of Material Cycles and Waste Management. Dordrecht, 14, 181-192.

Mohit, S., Manoj, D., Ramana, G. V., \& Sreekrishnan, T. R. (2018). Investigations on fine fraction of aged municipal solid waste recovered through landfill mining: Case study of three dumpsites from India. Waste Management \& Research, 0, 1-12. https://doi.org/10. 1177/0734242X18782393

Moldrup, P., Olesen, T., Gamst, J., Schjonning, P., Yamaguchi, T., \& Rolston, D. E. (2000). Predicting the gas diffusion coefficient in repacked soil: Water induced linear reduction model. Soil Science Society of America Journal, 5(64), 1588-1594. https://doi.org/ 10.2136/sssaj2000.6451588x

Moldrup, P., Olesen, T., Yoshikawa, S., Komatsu, T., \& Rolston, D. E. (2005). Predictive descriptive models for gas and solute diffusion coefficients in variably saturated porous media coupled to pore size distribution: III. Inactive pore space interpretations of gas diffusivity. Soil Science, 170, 867-880. https://doi.org/10.1097/ 01.ss.0000196770.45951.06

Oldenburg, C. M. (2015). EOS7CA Version 1.0: TOUGH2 module for gas migration in shallow subsurface porous media systems. Lawrence Berkeley National Laboratory Report LBNL-175204.

Parrodi, J. C., Hollen, D., \& Pomberger, R. (2017). Characterization of fine fractions from landfill mining: A review of previous landfill mining investigations. Proceeding of Sixteenth International Waste 
Management and Landfill Symposium, 2-6 October. Sardinia, Italy: CISA.

Peng, D. Y., \& Robinson, D. B. (1976). A new two-constant equation of state. Industrial \& Engineering Chemistry Research, 15, 59-64.

Pruess, K., Oldenburg, C. M., \& Moridis, G. J. (1999). TOUGH2 User's Guide Version 2. E.O. Lawrence Berkeley National Laboratory Report, LBNL 43134.

Quaghebeur, M., Laenen, B., Geysen, D., Nielsen, P., Pontikes, Y., van Gerven, T., \& Spooren, J. (2013). Characterization of landfilled materials: Screening of the enhanced landfill mining potential. Journal of Cleaner Production, 55, 72-83. https://doi.org/10.1016/ j.jclepro.2012.06.012

Resurreccion, A. C., Kawamoto, K., Komatsu, T., Moldrup, P., Sato, K., \& Rolston, D. E. (2007). Gas diffusivity and air permeability in a volcanic ash soil profile: Effects of organic matter and water retention. Soil Science, 172(6), 432-443. https://doi.org/10.1097/SS. 0b013e3180471c94

Rosin, P., \& Rammler, E. (1933). Laws governing the fineness of powdered coal. Journal of the Institute of Fuel, 7, 29-36.

Sakaki, T., Limsuwat, A., Smits, K. M., \& Illangasekare, T. H. (2008). Empirical two point a-mixing model for calibrating the $\mathrm{ECH} 2 \mathrm{O}$ EC-5 soil moisture sensor in sands. Water Resources Research, 44, W00D08. https://doi.org/10.1029/2008WR006870

Sri Lanka Ministry of Environment. (2011). Second national communication on climate change. Ministry of Environment. Democratic Socialist Republic of Sri Lanka (submitted to the UNFCCC secretariat).

Shanujah, M., Chamindu Deepagoda, T. K. K., Nasvi, M. C. M., Karunarathna, A. K., Shreedharan, V., Babu, G. L. S., ... Oldenburg, C. M. (2019). Gas diffusivity based characterization of stabilized solid waste from kurunagala open dump disposal site. $10^{\text {th }}$ International Conference on Structural Engineering and Construction Management.

Smits, K. M., Sakaki, T., Howinton, S. E., Peters, J. H., \& Illangasekara, T. H. (2013). Temperature dependence of thermal properties of sand across a wide range of temperature $\left(30-70{ }^{\circ} \mathrm{C}\right)$. Vadose Zone Journal, 12(1). https://doi.org/10.2136/vzj2012.0033

Stevenson, F. J. (1994). Humus chemistry: Genesis, composition, reactions. Hoboken, NJ: John Wiley \& Sons.

Townsend, T., Miller, W. L., Lee, H., \& Earle, J. F. K. (1996). Acceleration of landfill stabilization using leachate recycle. Journal of Environmental Engineering, 122(4), 263-268. https://doi.org/10.1061/ (ASCE)0733-9372(1996)122:4(263)

van Genuchten, M. Th. (1980). A closed-form equation for predicting the hydraulic conductivity of unsaturated soils. Soil Science Society of America Journal, 44, 892-898. https://doi.org/10.2136/sssaj1980. 03615995004400050002x

Visscher, A. D., \& Van Cleemput, O. (2003). Simulation model for gas diffusion and methane oxidation in landfill cover soils. Waste Management Journal, 23, 581-591. https://doi.org/10.1016/S0956053X(03)00096-5

Vidanaarachchi, C. K., Yuen, S. T. S., \& Pilapitiya, S. (2006). Municipal solid waste management in the Southern Province of Sri Lanka: Problems, issues and challenges. Waste Management, 26, 920-930. https://doi.org/10.1016/j.wasman.2005.09.013

Wallen, B. M., Smits, K. M., Sakaki, T., Howington, S. E., \& Chamindu Deepagoda, T. K. K. (2013). Thermal conductivity of binary sand mixtures evaluated through full water content range. Soil Science
Society of America Journal, 80(3), 592-603. https://doi.org/10.2136/ sssaj2015.11.0408

Whalen, S. C., \& Reeburgh, W. S. (1988). A methane flux time series for tundra environments. Global Biochemical Cycles, 2, 399-409. https://doi.org/10.1029/GB002i004p00399

Wolfsberge, T., Höllen, D., Sarc, R., Aldrian, A., Budischowsky, A., Zöscher, A., † Lorber, K.E. (2014). Landfill mining - case study: Characterization and treatment of excavated waste from Austrian sanitary landfill sites and estimation of the resource potential. Wellington, NZ: ISWA World Congress.

Bank World. 1999. What a waste: Solid waste management in Asia. In D. Hoornweg \& L. Thomas (Eds.), Washington, DC: Urban Development Sector Unit (UDSU), East Asia and Pacific Region.

Wraith, J. M., \& Or, O. (1998). Nonlinear parameter estimation using spreadsheet software. Journal of Natural Resources and Life Sciences Education, 27, 13-19.

Young, P. J., Parker, A., \& Brookes, B. (1982). Identification of trace gases and vapors from landfills and their environmental significance. AERE Report G, 2491, 527-531.

How to cite this article: Shanujah M, Deepagoda TKKC, Karunarathna AK, et al. Effects of "soil-like" particle size on gas transport and water retention properties in aged municipal solid waste from a Sri Lankan open dumpsite. Soil Sci. Soc. Am. J. 2020;84:1080-1093. https://doi.org/10.1002/saj2.20100.

\section{APPENDIX}

\section{Nomenclature}

$D_{\beta}^{\kappa} \quad$ Molecular diffusivity of component $\kappa$ in phase $\beta$ $\left(\mathrm{m}^{2} \mathrm{~s}^{-1}\right)$

g Gravitational acceleration of gravity vector $\left(\mathrm{m} \mathrm{s}^{-2}\right)$

$\boldsymbol{F}$ Darcy flux vector $\left(\mathrm{kg} \mathrm{m}^{2} \mathrm{~s}^{-1}\right)$

$\boldsymbol{k}$ Intrinsic permeability $\left(\mathrm{m}^{2}\right)$

$k_{\Gamma} \quad$ Relative permeability (-)

M Mass accumulation term $\left(\mathrm{kg} \mathrm{m}^{-3}\right)$

n Outward unit normal vector

$P$ Total pressure $\left(\mathrm{P}_{\mathrm{a}}\right)$

$P_{\mathrm{C}} \quad$ Capillary pressure $\left(\mathrm{P}_{\mathrm{a}}\right)$

$q$ Mass flux $\left(\mathrm{kg} \mathrm{m}^{-2} \mathrm{~s}^{-1}\right)$

S Saturation (-)

$t$ Time (s)

$T$ Temperature $\left({ }^{\circ} \mathrm{C}\right)$

$\mathrm{V}$ Volume $\left(\mathrm{m}^{3}\right)$

$X_{\beta}^{\kappa} \quad$ Mass fraction with phase subscript and component superscript (-)

$\mathrm{X}$ X-coordinate $(\mathrm{m})$

$\mathrm{Y} \quad \mathrm{Y}$-coordinate $(\mathrm{m})$

Z Z-coordinate (positive upward) (m)

$T_{\mathrm{D}}$ Exponent for temperature dependence of diffusivity $(-)$

$\mathrm{x}$ mole farction 


\section{Greek symbols}

a $1 / \mathrm{P}_{\mathrm{o}}$ van Genuchten's capillary pressure function $\left(\mathrm{Pa}^{-1}\right)$

$\beta$ Phase index (subscript)

$\Gamma \quad$ Surface area $\left(\mathrm{m}^{2}\right)$

$\kappa \quad$ Mass components (superscript)

$\lambda$ van Genuchten's $m(-)$

$\mu$ Dynamic viscosity $\left(\mathrm{kg} \mathrm{m}^{-1} \mathrm{~s}^{-1}\right)$

$\rho$ Density $\left(\mathrm{kg} \mathrm{m}^{-3}\right)$

$\tau$ Tortuosity (-)
$\Phi \quad$ Porosity $\left(\mathrm{m}^{3} \mathrm{~m}^{-3}\right)$

$\varepsilon \quad$ Air-filled porosity

\section{Subscripts and superscripts}
g Gas
$\ell \quad$ Liquid
W Water
S Saturation
max Maximum
$r$ Residual
0 Reference value 